\title{
The Potency of Seaweed Sulfated Polysaccharides for the Correction of Hemostasis Disorders in COVID-19
}

\author{
Tatyana A. Kuznetsova ${ }^{1, *}$, Boris G. Andryukov ${ }^{1,2}{ }^{\mathbb{D}}$, Ilona D. Makarenkova ${ }^{1} \mathbb{D}$, Tatyana S. Zaporozhets ${ }^{1}$, \\ Natalya N. Besednova ${ }^{1}$, Ludmila N. Fedyanina ${ }^{2}$, Sergey P. Kryzhanovsky ${ }^{3}$ and Mikhail Yu. Shchelkanov ${ }^{1,2,4,5}$
}

1 G.P. Somov Institute of Epidemiology and Microbiology, Russian Federal Service for Surveillance on Consumer Rights Protection and Human Wellbeing, 690087 Vladivostok, Russia; andrukov_bg@mail.ru (B.G.A.); ilona_m@mail.ru (I.D.M.); niiem_vl@mail.ru (T.S.Z.); besednoff_lev@mail.ru (N.N.B.); adorob@mail.ru (M.Y.S.)

2 School of Biomedicine, Far Eastern Federal University (FEFU), 690091 Vladivostok, Russia; fedyanina.ln@dvfu.ru

3 Medical Association of the Far Eastern Branch of the Russian Academy of Sciences, 690022 Vladivostok, Russia; priemmodvoran@mail.ru

4 Federal Scientific Center of the Eastern Asia Terrestrial Biodiversity, Far Eastern Branch of Russian Academy of Sciences, 690091 Vladivostok, Russia

5 National Scientific Center of Marine Biology, Far Eastern Branch of Russian Academy of Sciences, 690091 Vladivostok, Russia

* Correspondence: takuznets@mail.ru; Tel.: +7-4-232-442-446

\section{check for}

updates

Citation: Kuznetsova, T.A.;

Andryukov, B.G.; Makarenkova, I.D.;

Zaporozhets, T.S.; Besednova, N.N.;

Fedyanina, L.N.; Kryzhanovsky, S.P.;

Shchelkanov, M.Y.. The Potency of

Seaweed Sulfated Polysaccharides for the Correction of Hemostasis

Disorders in COVID-19. Molecules

2021, 26, 2618. https://doi.org/

$10.3390 /$ molecules26092618

Academic Editor: Xiangkai Li

Received: 22 March 2021

Accepted: 28 April 2021

Published: 29 April 2021

Publisher's Note: MDPI stays neutral with regard to jurisdictional claims in published maps and institutional affiliations.

Copyright: (c) 2021 by the authors. Licensee MDPI, Basel, Switzerland. This article is an open access article distributed under the terms and conditions of the Creative Commons Attribution (CC BY) license (https:// creativecommons.org/licenses/by/ $4.0 /)$.

\begin{abstract}
Hemostasis disorders play an important role in the pathogenesis, clinical manifestations, and outcome of COVID-19. First of all, the hemostasis system suffers due to a complicated and severe course of COVID-19. A significant number of COVID-19 patients develop signs of hypercoagulability, thrombocytopenia, and hyperfibrinolysis. Patients with severe COVID-19 have a tendency toward thrombotic complications in the venous and arterial systems, which is the leading cause of death in this disease. Despite the success achieved in the treatment of SARS-CoV-2, the search for new effective anticoagulants, thrombolytics, and fibrinolytics, as well as their optimal dose strategies, continues to be relevant. The wide therapeutic potential of seaweed sulfated polysaccharides (PSs), including anticoagulant, thrombolytic, and fibrinolytic activities, opens up new possibilities for their study in experimental and clinical trials. These natural compounds can be important complementary drugs for the recovery from hemostasis disorders due to their natural origin, safety, and low cost compared to synthetic drugs. In this review, the authors analyze possible pathophysiological mechanisms involved in the hemostasis disorders observed in the pathological progression of COVID-19, and also focus the attention of researchers on seaweed PSs as potential drugs aimed to correction these disorders in COVID-19 patients. Modern literature data on the anticoagulant, antithrombotic, and fibrinolytic activities of seaweed PSs are presented, depending on their structural features (content and position of sulfate groups on the main chain of PSs, molecular weight, monosaccharide composition and type of glycosidic bonds, the degree of PS chain branching, etc.). The mechanisms of PS action on the hemostasis system and the issues of oral bioavailability of PSs, important for their clinical use as oral anticoagulant and antithrombotic agents, are considered. The combination of the anticoagulant, thrombolytic, and fibrinolytic properties, along with low toxicity and relative cheapness of production, open up prospects for the clinical use of PSs as alternative sources of new anticoagulant and antithrombotic compounds. However, further investigation and clinical trials are needed to confirm their efficacy.
\end{abstract}

Keywords: seaweed polysaccharides; fucoidans; carrageenans; ulvans; anticoagulants; thrombolytics; fibrinolytics; thrombin inhibitors; hemostasis disorders; blood coagulation; COVID-19 associated coagulopathy; SARS-CoV-2 


\section{Introduction}

Hemostasis disorders play an important role in the pathogenesis, clinical manifestations, and outcome of COVID-19. First of all, the hemostasis system suffers due to a complicated and severe course of COVID-19. In the initial stage of the disease, a significant number of COVID-19 patients develop signs of hypercoagulation, and in the later stages, signs of disseminated intravascular coagulation (DIC) syndrome. Coagulation disorders and their clinical manifestations have a number of differences from the classic DIC syndrome, and are named COVID-associated coagulopathy [1-3].

Patients with severe COVID-19 have a tendency toward thrombotic complications in the venous and arterial systems, which is the leading cause of death in this disease [1,4-6].

The treatment of COVID-19 patients and, in particular, correction of the hemostasis disorders is a difficult problem. Despite the data on the effectiveness of heparin drugs in reducing mortality in severe COVID-19 patients, and despite thromboprophylaxis [7,8], the development of venous and arterial thromboembolic complications has been reported. There is also a problem with the optimal dosage of anticoagulant agent [5,9-11]. Thus, there are a number of unresolved issues regarding the use of these drugs.

In this regard, there is a need to use the effective anticoagulants and antithrombotic drugs, as well as their optimal dosages, in the treatment of COVID-19 patients and for the prevention of thrombotic complications $[7,12,13]$.

Despite the success achieved in SARS-CoV-2 therapy, the development of more effective treatment regimens for this infection with the inclusion of anticoagulants, thrombolytics, and fibrinolytics, as well as the search for new effective drugs of this pharmacological group, does not lose relevance. The wide therapeutic potential of seaweed sulfated polysaccharides (PSs), including anticoagulant, thrombolytic, and fibrinolytic activities, opens up a new possibilities for their study in experimental and clinical trials.

This review presents current literature data on the anticoagulant, antithrombotic, and fibrinolytic activities of seaweed PSs, depending on their structural features (content and position of sulfate groups on the main chain of PS, molecular weight, monosaccharide composition and type of glycosidic bonds, the degree of PS chain branching, etc.). The mechanisms of PS action on the hemostasis system are discussed compared to heparin. The issues of oral bioavailability of PSs, important for their clinical use as oral anticoagulant and antithrombotic agents, are considered. The combination of the anticoagulant, thrombolytic, and fibrinolytic properties, along with low toxicity and the relative low cost of their production, opens up prospects for the clinical use of PSs as alternative sources of new anticoagulant and antithrombotic compounds, including those aimed to correction hemostasis disorders in COVID-19 patients.

\section{Anticoagulant, Antithrombotic, and Fibrinolytic Activities of Seaweed Sulfated Polysaccharides}

Polysaccharides (PSs) are the main structural components of brown, red, and green seaweed, the content of which can be up to $76 \%$ of the dry weight [14]. Seaweed sulfated PSs possess a wide spectrum of biological activity, including immunoregulatory, antitumor, anti-inflammatory, antiviral and antibacterial, antioxidant, anticoagulant, etc. This excellent biological activity is attributed to their unique biological structure.

The anticoagulant properties of seaweed sulfated PSs are widely described in the scientific literature. Springer et al. [15] were the first to detect anticoagulant activity in sulfated PS (fucoidan) from the brown alga Fucus vesiculosus. Further numerous studies have confirmed that seaweed sulfated PSs are strong anticoagulants and may be alternative sources of new anticoagulant compounds.

The study of seaweed sulfated PS anticoagulant activity and its mechanisms is carried out mainly in connection with the structural features of these compounds. So, sulfated PSs of brown algae (fucoidans) represent the family of fucose-containing homo- and heteropolysaccharides from polysaccharides with a high content of uronic acids and low fucose and sulfate contents for practically pure $\alpha$-L-fucans with the main component of 
polysaccharide-fucose. Except for fucose, these polysaccharides can contain minor amounts of other monosaccharides (galactose, mannose, xylose, glucose) and also sulfates, uronic acids, acetyl groups, and proteins [16-18] (Figure 1).
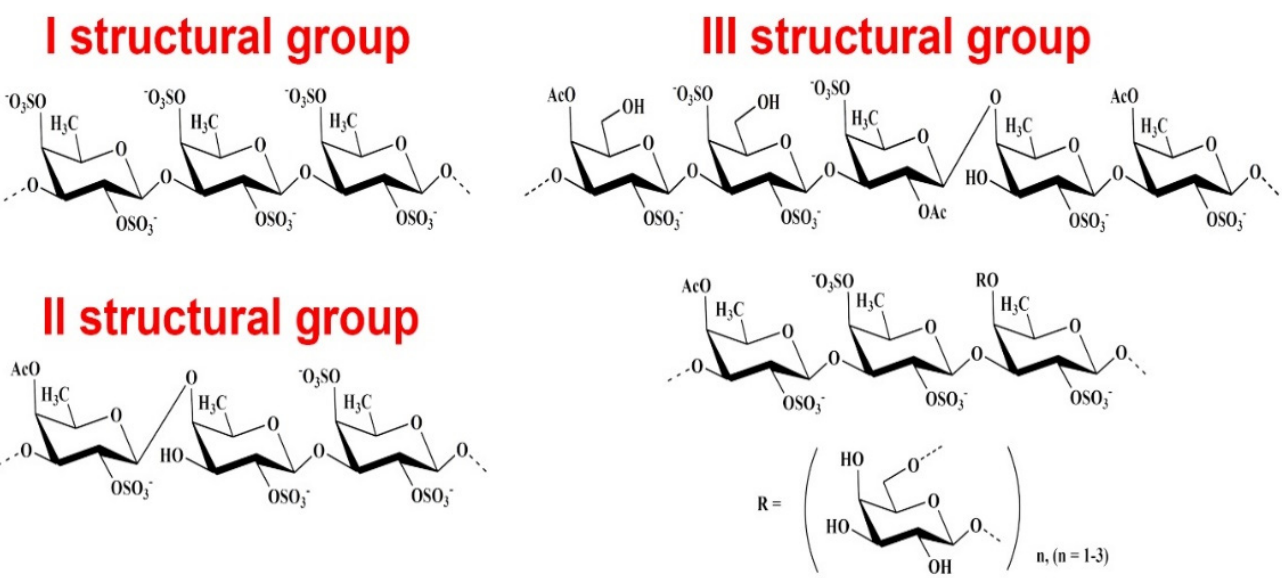

Figure 1. Structural fragments of fucoidans. Most of the known fucoidans belong to three structural types: the first type contains $(1 \rightarrow 3)$-linked $L$-fucopyranose residues in the main chain; the second type is alternating $(1 \rightarrow 3)$ - and $(1 \rightarrow 4)$-linked residues of L-fucopyranose; the third type of fucoidans (galactofucans) contains fucose and galactose residues, and sometimes these monosaccharides are represented in the structures of fucoidans in comparable amounts. In addition to fucose, fucoidans often contain small amounts of other monosaccharides.

The backbone of the chemical structure of green algae sulfated PSs (ulvans) is composed of glucuronic acid and repeating disaccharide units (xylose and rhamnose): $\alpha$ - and $\beta$-( $1 \rightarrow 4$ )-linked sugar residues (such as $\alpha-1,4$ - and $\alpha-1,2,4$-linked $L$-rhamnose), $\beta$-1,4- and terminally linked d-glucuronic acid, and $\beta$-1,4-linked d-xylose [19-23] (Figure 2).
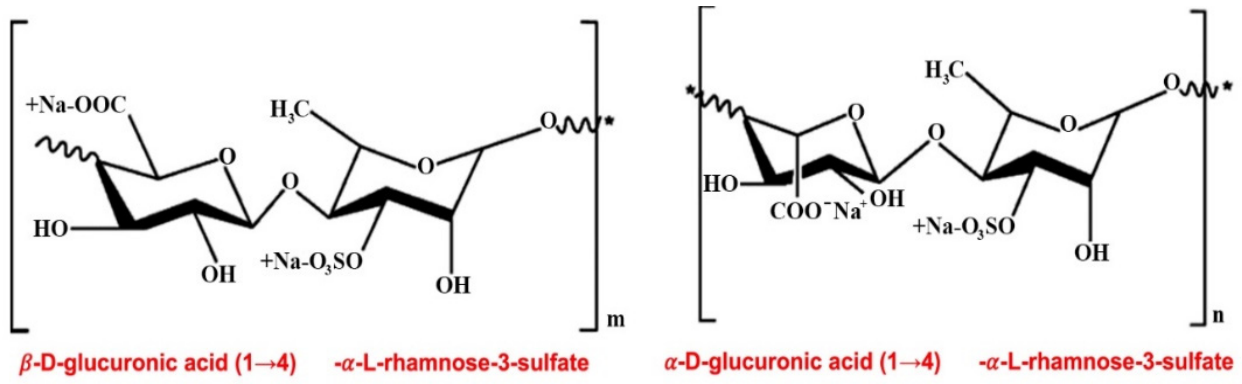

Figure 2. Structures of the main repeating disaccharides constituting ulvans. The backbone of the chemical structure of ulvans is composed of glucuronic acid and repeating disaccharide units (xylose and rhamnose): $\alpha$ - and $\beta$-(1-4)-linked sugar residues (such as $\alpha$-1,4- and $\alpha-1,2,4$-linked $L$-rhamnose), $\beta-1,4$ - and terminally linked d-glucuronic acid, and $\beta$-1,4-linked d-xylose.

Carrageenans are sulfated linear PSs of red algae, whose chemical structure is based on a repeating disaccharide unit consisting of D-galactose residues connected via alternating $\beta-1 \rightarrow 4$ - and $-1 \rightarrow 3$-glycosidic bonds. Thus, sulfated PSs of red algae of the class Rhodophyceae consist of repeating dimers of $\alpha-1,4$ - D-galactose, which are connected via alternating $\alpha-1 \rightarrow 3$ - and $\beta-1 \rightarrow 4$-glycosidic bonds and substituted by one ( $\mathrm{k}$-carrageenan), two ( -carrageenan), or three ( $\lambda$-carrageenan) sulfate ester groups in each repeating unit [24-26] (Figure 3). 


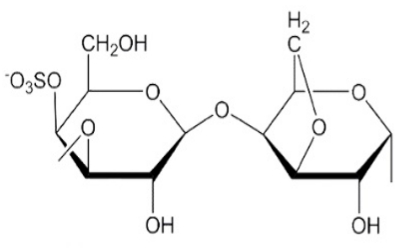

kappa carrageenan

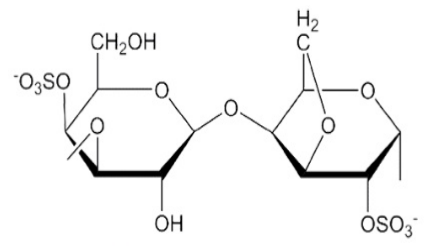

iota carrageenan

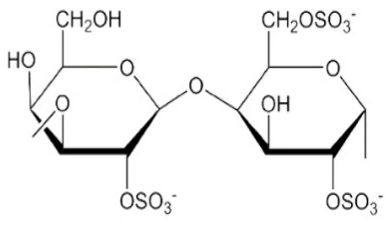

lambda carrageenan

Figure 3. Structural fragments of carrageenans. Carrageenans are sulfated linear PSs whose chemical structure is based on a repeating disaccharide unit consisting of D-galactose residues connected via alternating $\beta-1 \rightarrow 4$ - and $-1 \rightarrow 3$-glycosidic bonds. Sulfated PSs of red algae of the class Rhodophyceae consist of repeating dimers of $\alpha-1,4$ - D-galactose, which are connected via alternating $\alpha-1 \rightarrow 3$ - and $\beta-1 \rightarrow 4$-glycosidic bonds and substituted by one ( $\kappa$-carrageenan), two ( $\mathrm{l}$-carrageenan), or three ( $\lambda$-carrageenan) sulfate ester groups in each repeating unit.

The relationship between anticoagulant activities of PSs and their chemical structure is complex. A number of factors, such as molecular weight (MW), monosaccharide composition, and content of sulfates, as well as the nature of the bonds in the polysaccharide chain, have a significant influence on the anticoagulant activity. At the same time, according to many researchers, the degree of anticoagulant action of sulfated PSs is closely correlated with their structure and function, and varies significantly from weakly expressed or absent to high.

First of all, the content of sulfates has the most significant effect on the anticoagulant potential of these PSs. A number of authors confirmed this relationship in well-studied fucoidans from brown algae with different content of sulfates, and showed that desulfated fractions of fucoidans were inactive in coagulological tests [27-30]. The results obtained by these authors also indicate that the PS fractions from different types and species of brown algae, enriched with sulfates, but poor with uronic acids, exhibit relatively high activity, while the fractions with the inverse ratio of these structural components have a weaker anticoagulant activity. As for PSs from different types of green algae, it also was demonstrated that high-molecular-weight sulfated galactans with a high content of sulfates have a higher anticoagulant activity than low-molecular-weight PSs with a low content of sulfates [31-33].

Thus, the authors of one of the recent works reported that the PSs obtained by additional sulfation fraction from Ulva rigida, called ULVAN-02 (while the content of sulfates increased to $20 \%$ compared to the ULVAN-01 fraction containing $11 \%$ of sulfates) showed a significant increase in anticoagulant activity regardless of the coagulation pathway [33]. This activity was comparable to that of heparin, and was higher than that of the commercial anticoagulant drug Lovenox ${ }^{\circledR}$ (Sanofi-Aventis, Rock Hill, SC, USA). According to the authors, the most probable hypothesis explaining the anticoagulant activity of the ULVAN-02 fraction is that the geometric correspondence between PSs and their binding sites with coagulation factors increase with increasing degree of sulfation. At the same time, hypersulfated zones provide a higher physical ability to interact, which further increases the degree of PS binding. Taking into account the presented data, it can be assumed that the potential anticoagulants are PSs with a high degree of sulfation.

However, as noted by other authors, PSs from various green algae species with a high content of sulfates (26-35\%) showed no activity with respect to the external coagulation pathway [34,35]. According to Silva et al. [29] and Yoon et al. [36], the anticoagulant activity of fucoidans from various algae species did not correlate with the content of sulfate groups, but were associated with the position of sulfates. It follows from these data that the degree of sulfation is not the only parameter that affects the anticoagulant activity of PSs. The monosaccharide composition and type of glycosidic bonds, the degree of chain branching, and the position of the sulfate groups on the main chain of the PSs are important too. This dependency is also very ambiguous. As is known, the main structural monosaccharides in the composition of PSs are fucose, galactose, mannose, xylose, and rhamnose in different ratios. Thus, it was found that a high content of fucose (as well as a sulfate residue) 
and a low content of other neutral sugars can contribute to the manifestation of high anticoagulant activity of fucoidans $[29,36]$. Therefore, the ratio of sulfates/total residual sugars has a certain value for the manifestation of anticoagulant properties (even to a greater extent than the degree of sulfation).

An important factor influencing the anticoagulant activity of PSs is the MW. According to Yang et al. [37], fucoidans exhibit the strongest anticoagulant activity in the range of MW from 10 to $300 \mathrm{kDa}$. Pomin et al. [38] confirmed the relationship between MW and anticoagulant activity and showed that a decrease in MW of fucoidan from Laminaria brasiliensis led to a sharp decrease in the latter. Boisson-Vidal et al. [39] also noted that the anticoagulant and antithrombotic activity of fucoidan fractions from Ascophyllum nodosum increased with increasing MW and sulfate content. The fucoidan fractions in which the natural structure was not degraded (i.e., the sulfate group was intact) were more active in the manifestation of the anticoagulant action than fractions with an equivalent MW and degree of sulfation, but modified by partial desulfation. Lahrsen et al. [40] also showed that the anticoagulant activity of fucoidan from F. vesiculosus and 18 gradually depolymerized fractions decreased with decreasing MW.

Therefore, some researchers believe that the anticoagulant activity of PSs is associated with a high MW (up to some hundred $\mathrm{kDa}$ ), while others consider the lower limit of this activity to be $10 \mathrm{kDa}$, but in general, the authors concluded that different fucoidan fractions have their own optimal MW for the manifestation of such activity.

Numerous data indicate the antithrombotic activity of seaweed sulfated PSs. Thus, the studies of Choi et al. [41] demonstrated the thrombolytic activity of various fucoidan fractions from the brown algae Fucus evanescens and Undaria pinnatifida. The authors associated this activity with an increase in the level of t-PA (tissue plasminogen activator). The fucoidans inhibit the tPA-PAI-1 (plasminogen activator inhibitor-1) complex, indicating activation of plasma tissue-type plasminogen activator is a mechanism of fucoidanmediated thrombolysis in a mouse thrombosis model [41]. Min et al. [42] also showed thrombolytic effects of fucoidans from different types of algae in a mouse arterial thrombosis model. Fucoidan infusion to mice resulted in a several-fold increase in t-PA levels compared to the control group (healthy animals) and the group of untreated animals with thrombosis $(p<0.01)$. The authors concluded that the mechanism of fucoidan-mediated thrombolysis is realized through the release of vascular endothelial t-PA, depending on the dose and type of algae [42]. Sulfated PSs from green alga Monostroma nitidum showed significant anticoagulant and antithrombotic properties in vitro and in vivo. The authors considered that this PS may be a promising drug for the prevention and treatment of thromboembolic diseases [43]. Juenet et al. [44] also investigated the thrombolytic effect of fucoidan in a mouse venous thrombosis model by monitoring the platelet density in the thrombus with intravital microscopy. Polysaccharide-poly(isobutylcyanoacrylate) nanoparticles functionalized with fucoidan (Algues \& Mer, Ouessant, France) and loaded with rt-PA (recombinant tissue plasminogen activator) were designed to accumulate on the thrombus. These nanoparticles showed the greatest thrombolytic effect. The platelet density was decreased to $30 \%$, whereas after the introduction of nanoparticles without fucoidan, the value of this parameter was $66 \%$. The authors believe that the nanoparticles not only protect rt-PA, but also enhance its thrombolytic activity due to the ability of fucoidanfunctionalized polymer nanoparticles targeting P-selectin [44]. This work provides the evidence for the concept of fucoidan-based carriers for targeted thrombolysis.

In addition, the fibrinolytic activity of fucoidans were shown. The mechanisms of fibrinolytic activity and activation of the endogenous fibrinolytic system are associated with an increase in the potential activity of the plasmin system [32,41,45,46]. Thus, Liu et al. [32] assessed the fibrinolytic and thrombolytic activity of sulfated PSs from the green alga Monostroma angicava and its low-molecular-weight fragments using in vitro and in vivo experiments (by D-dimer, fibrin degradation products, PAI-1, and clot lytic rate assays). The results showed that PSs with MW of 24-240 kDa possessed high fibrinolytic and thrombolytic activities [32]. 
As a result, the presented data of numerous studies indicate that the anticoagulant, fibrinolytic, and thrombolytic activity critically depends on some structural features. The features are the content and position of sulfate groups on the main chain of PSs, MW, monosaccharide composition and type of glycosidic bonds, the degree of PS chain branching, etc., but the degree of sulfation and monosaccharide composition are most important.

As for the mechanisms of anticoagulant activity of PSs, the study is usually carried out in a comparative aspect to heparin, the most widely used anticoagulant in medicine. However, the clinical use of heparin causes a number of side effects, including hemorrhagic effects and the occurrence of heparin-induced thrombocytopenia, thrombosis, hyperkalemia, osteopenia, etc. [47-49]. In addition, the therapeutic use of heparin is limited by parenteral administration (mainly due to the negative charge and large MW), in contrast to the new oral anticoagulants [50].

In this respect, low-toxic seaweed sulfated PSs represent an alternative to heparin.

The mechanisms of anticoagulant action of sulfated PSs from seaweed and heparin have a number of differences, as evidenced by the results of a number of studies. An important role in the implementation of the mechanisms of anticoagulant activity of sulfated PS, as well as heparin, belongs to thrombin.

A number of authors associate the anticoagulant activity of fucoidans with an inhibitory effect on thrombin (factor IIa) and factor Xa. This mechanism plays a leading role in the inhibition of thrombin formation by fucoidan [27,28,51].

For example, it has been shown that fucoidan from the brown alga Fucus evanescens provides an inhibitory effect on thrombin (IIa) and factor Xa, both at the initial and subsequent stages of coagulation pathways. The authors believe that fucoidan, like heparin, converts AT III from a slow-acting to a fast-acting thrombin inhibitor [52,53] (Figure 4).

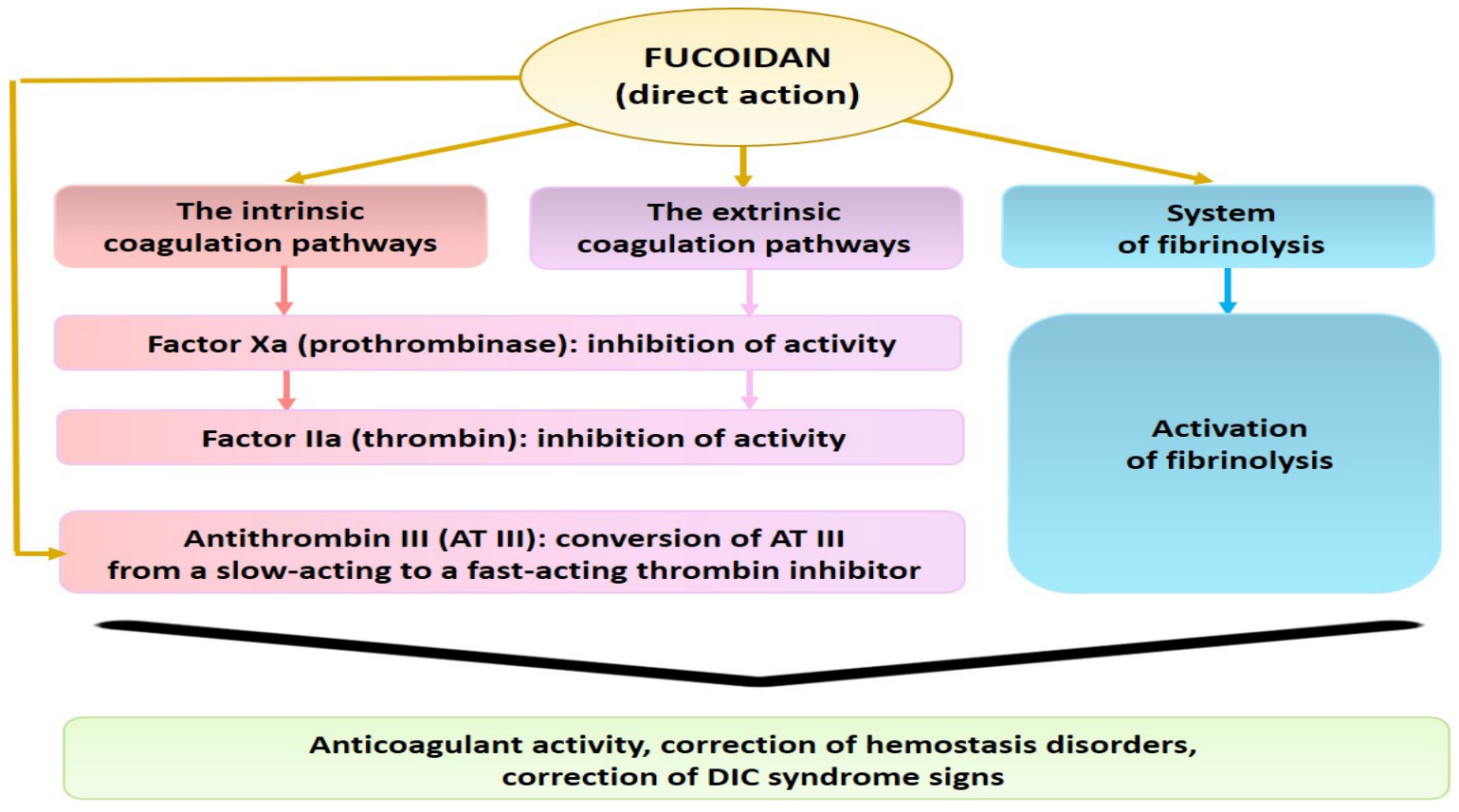

Figure 4. Scheme of the mechanisms of $F$. evanescens fucoidan action on the hemostasis system.

According to Jung et al. [54], fucose-containing sulfated PSs from Ecklonia cava strongly and selectively (factors VII, X, and II) enhanced ATIII-mediated coagulation-factor inhibition in both the extrinsic and common coagulation pathways [54]. According to Melo et al. [51], the anticoagulant activity of sulfated PSs is achieved mainly due to the potentiation of plasma cofactors, including AT III above. In particular, sulfated PSs (galactans) can bind to AT III above. However, the authors emphasize that the structural basis of the interactions is very complex due to the heterogeneity of these PSs. The interaction of sulfated 
galactans with the antithrombin/thrombin complex requires significantly longer chains than heparin, and these connections are made with other sites [51]. Becker et al. [55] emphasized that the nature of the specific interaction of sulfated PSs and galactans with AT III can determine their differences with heparin in the mechanisms of anticoagulantgc gcactivity.

As presented above, the study of the anticoagulant effects of PSs was conducted using in vitro or in vivo experiments with parenteral administration. Polysaccharides are one of the most studied molecules as potential antithrombotic agents, and questions of oral bioavailability are important for the clinical use of PSs. As noted by Wang et al. [56], in future studies, a clear understanding of technical problems concerning the preparation, quality standards, and administration of fucoidan, including oral, must be defined to fully harness its therapeutic potential.

In this regard, numerous studies demonstrated the biological effects of sulfated PSs, including anticoagulant activity, with oral administration. For example, long-term (up to 6 months) oral administration of fucoidan from Laminaria japonica to Wistar rats at a dose of $300 \mathrm{mg} / \mathrm{kg}$ of body weight per day did not show significant side effects, but increasing the dose to 900 and $2500 \mathrm{mg} / \mathrm{kg}$ significantly prolonged the time of blood coagulation [57]. Fucoidans from F. vesiculosus and L. japonica (MW 10-300 kDa), administered subcutaneously or orally, did not cause negative changes in dogs with hemophilia A. Moreover, fucoidans led to normalization of hemostasis parameters [58]. Oral administration of fucoidan from Cladosiphon okamuranus to Wistar rats at a dose of $600 \mathrm{mg} / \mathrm{kg}$ per day did not cause significant changes in hemostasis parameters, while higher doses $(1200 \mathrm{mg} / \mathrm{kg})$ caused an increase the time of blood coagulation [59]. Zhao et al. [60] conducted a comparative study of the oral absorption, bioavailability, and antithrombotic activity of two fractions of fucoidan from L. japonica with low and medium MW on a model of electricity-induced arterial thrombosis in rats. The authors showed that a single administration of low-molecularweight fucoidan at a dose of 400 and $800 \mathrm{mg} / \mathrm{kg}$ for 30 days inhibited the formation of arterial thrombosis, which was accompanied by moderate anticoagulant activity, significant antiplatelet activity, and effective fibrinolysis. The authors recommended this fucoidan as an oral antithrombotic agent, which is a highly desirable property of oral drugs [60].

\section{Possible Pathophysiological Mechanisms Involved in the Hemostasis Disorders in the Pathological Progression of COVID-19}

\subsection{Systemic Endothelial Dysfunction}

Hemostasis disorders in COVID-19 are largely determined by systemic endothelial dysfunction. Damage to the endothelium is caused by the fact that SARS-CoV-2 virus enters the human body and binds with a high avidity to the ACE2 (angiotensin-converting enzymegcu 2) receptor, present on endothelial cells and on the surface of type II alveolocytes [61]. This enzyme performs a protective function on endothelial cells and alveolocytes due to its anti-inflammatory, antithrombin, and antioxidant activities [62]. Direct evidence of endothelial-cell infection with the SARS-CoV-2 virus was found, leading to diffuse endothelial damage and death of the affected cells [61].

Systemic endothelial dysfunction and its activation serve as prerequisites for further pathophysiological events. Damaged or cytokine-activated endothelial cells, as well as monocytes, produce tissue factor (TF). TF plays a key role in the pathogenesis of hypercoagulation disorders in COVID-19. As a result, excessive formation of thrombin occurs, which leads to the formation of numerous thrombus in various organs, primarily leading to pulmonary thrombosis. This implication is called COVID-associated coagulopathy. According to some authors, thrombotic coagulopathy is present in almost three-quarters of COVID-19 patients admitted to the intensive care unit [2,63-65]. Due to the formation of microthrombi and impaired blood flow in the lungs, the death of lung-tissue cells occurs.

A significant contribution to the pathogenesis of hemostatic disorders and the development of thrombosis is made by hypoxemia resulting from damage to lung tissue [66-68].

In SARS-CoV-2 infection, hyperproduction of chemokines and proinflammatory cytokines (TNF, IL-1, IL-6, IL-8) and hyperactivation of immune cells, known as a cytokine storm, contribute to increased thrombin production and the likelihood of developing throm- 
bosis, as well as the development of multiorgan failure (PON) in patients $[3,63,69,70]$. IL-6 is known to be a key activator of coagulopathy by inducing TF expression and increasing production of fibrinogen and platelets [71].

\subsection{COVID-19-Associated Coagulopathy (CAC). Thrombotic Complications}

Hypercoagulation abnormalities, which are detected at the initial stages of COVID19, differ from the usual disseminated intravascular coagulation (DIC) syndrome, which develops in the later stages as the disease progresses, into the development of multi-organ failure, the addition of infectious complications, and sepsis [2,3,64].

Unlike the pattern seen in classic DIC syndrome, COVID-19-associated coagulopathy (CAC) characterized by minimal prolongation of coagulation-based laboratory parameters (activated partial thromboplastin time (APTT) and/or prothrombin time (PT)), or by a complete absence of changes in these parameters [64,72]. Mild thrombocytopenia (platelet count 100-150 $\times 10^{9} / \mathrm{L}$ ) is also noted, while hypofibrinogenemia is rarely detected [73], or an increased level of fibrinogen is noted [72]. According to Yang et al. [74] and Liu et al. [75], thrombocytopenia has been observed in $18-36 \%$ of hospitalized patients with COVID-19, but is usually not severe.

A common complication of severe SARS-CoV-2 is venous (VTE) or arterial (ATE) thromboembolism, which is also the leading cause of death in this disease $[5,63,76]$.

Venous thromboembolism (VTE) manifests as deep vein thrombosis (DVT) and pulmonary embolism (PE). As Klok et al. [5] noted, the most common thrombotic complication in COVID-19 patients was PE.

Arterial (ATE) thromboembolism is manifested by myocardial infarction, ischemic stroke, thrombosis and embolism of the peripheral arteries, and microvascular thrombotic disorders, which are often documented at autopsy [5,76]. According to Klok et al. [5], the incidence of thrombotic complications is $16-69 \%$ in patients with COVID-19 admitted to intensive care.

\subsection{Thrombocytopenia: The Role of Platelets in Thromboembolism}

Platelets play a key role in the development of arterial thromboembolism [77], and platelets are a potential target for the prevention of complications in COVID-19 [78].

In COVID-19 patients, the platelet count is often normal or mildly reduced, and according to N. Tang et al., thrombocytopenia occurs only in $12-36 \%$ of patients, and only in $5 \%$ of patients, the platelet counts are $<100 \times 10^{9} / \mathrm{L}$ [3]. Despite this, severe thrombocytopenia correlates with disease progression, as more than 55\% of fatal COVID-19 patients have platelet counts of $<100 \times 10^{9} / \mathrm{L}$. Thus, Yang et al. [74] noted that the intrahospital lethality was increased threefold in COVID-19 patients with thrombocytopenia.

Considering the mechanisms of thrombocytopenia in COVID-19 patients, the authors admit their multifactorial etiology, including cytokine storm, direct cytopathic effect of the virus on the bone marrow, and the formation of autoimmune complexes. This results in the destruction of platelets, inducing damage to the endothelium of pulmonary capillaries, causing platelet activation, aggregation, and reduction of circulating platelets [79,80]. The other authors [81] add that thrombocytopenia develops due to the fact, that viruses cause extensive damage to the bronchoalveolar tissue and the associated endothelial cells. This results in the intense platelet recruitment to the lungs and their consumption due to intense activation, which leads to depletion of the peripheral platelet count [81]. There are other mechanisms of thrombocytopenia in COVID-19, including the production of autoantibodies or immune complexes that mediate clearance and direct infection of hematopoietic progenitor cells and the megakaryocyte line, resulting in decreased platelet production [82].

Based on the above, it follows that monitoring the platelet count during hospitalization is very important for the prognosis in patients with COVID-19. 


\section{Treatment Strategies of COVID-19-Induced Hypercoagulation and the Potency of Seaweed Sulfated PSs for the Correction of Hemostasis Disorders}

The treatment of COVID-19 patients, and in particular hemostasis disorders, is challenging and a difficult issue, since the pathogenesis of the disorders is not completely clear.

Addressing the need for the use of anticoagulants, their optimal dosage in the prevention and treatment of patients with COVID-19, and the control of anticoagulant therapy are important issues. Heparin drugs are often used as anticoagulants in the treatment of patients with COVID-19. There is unfractionated heparin (UFH)-first-generation preparations called heparin, which are a mixture of PSs with a molecular weight (MW) in the range of 2-30 kDa (with a predominance of high-molecular fractions of glycosaminoglycan), and low-molecular-weight heparin (LMWH), obtained by chemical or enzymatic hydrolysis of UFH and having a molecular weight of 3-7 kDa.

The mechanism of anticoagulant action of heparin is to inhibit the activity of thrombin (clotting factor IIa), which catalyzes the conversion of fibrinogen to fibrin and some other reactions in the hemostatic system. The antithrombin activity of heparin depends on the presence of the plasma protein antithrombin III (AT III). When heparin binds to AT III, conformational changes occur in the latter molecule, which allow it to quickly connect to the active center of thrombin and other serine proteases (factors IXa, Xa, XIa and XIIa, kallikrein, and plasmin) [83]. Therefore, heparin inhibits thrombosis, contributing to the inactivation of thrombin by its physiological inhibitor AT III. In the presence of heparin, the inactivation of thrombin by antithrombin III is accelerated about 1000-fold. Slightly less important for the manifestation of the anticoagulant effect of heparin is the "heparin II cofactor" (HC II), the second heparin-dependent thrombin inhibitor other than AT III, which neutralizes thrombin only at high concentrations of heparin in the blood plasma $[84,85]$.

Both UFH and LMWH form complexes with AT III. However, if the UFH-AT III complex equally inhibits thrombin (factor IIa) and factor Xa, as well as other enzyme blood-clotting factors (Hageman factor, factors IX, XI, XII, etc.), then the anti-Xa activity prevails in LMWH [83,86-88].

Among the direct acting parenteral anticoagulants, it is recommended to give preference to LMWH compared to UFH, since the inhibitory activity of LMWH is stronger toward factor $\mathrm{Xa}$, and LMWH rarely causes such complications as heparin-induced thrombocytopenia and osteoporosis. Qian et al. [89] observed a reduction of treatment duration in patients with acute exacerbation of chronic obstructive pulmonary disease receiving ventilatory support using LMWH. ISTH interim guidance recommends LMWH as a first-line therapy for the prophylaxis of VTE in hospitalized patients with COVID-19 [8]. The synthetic drug fondaparinux has also been shown to be effective for the prevention of VTE in older acute medical patients and in reducing total mortality [90].

According to Tang et al. [7], LMWH contributed to a decrease in mortality in patients with sepsis-induced coagulopathy. The same author has shown the effectiveness of enoxaparin for prophylactic coagulation abnormalities in COVID-19 patients.

With regard to the dosage of heparin, a prophylactic dose of LMWH is recommended for the prevention of VTE in hospitalized patients with COVID-19, and a therapeutic dose of LMWH is recommended for patients with significantly elevated D-dimer concentrations [91].

Therefore, taking into account the pathogenesis, prevention, and treatment regimens for severe complications of COVID-19, LMWH are included in the treatment protocols for all hospitalized patients. LMWH is also recommended for use in the outpatient setting. The administration of LMWH, the duration of its use, and the dose should be determined taking into account the risk factors for each patient in combination with laboratory monitoring.

Prospective clinical trials are ongoing to confirm the benefits of using anticoagulants to improve the survival of COVID-19-patients.

In addition, direct oral anticoagulants are used in COVID-19 patient therapy. However, as Testa et al. [92] have shown, when used concomitantly with antiviral agents, the latter, especially those that interact with P-glycoprotein and/or cytochrome P450-based metabolic 
pathways, can alter the pharmacokinetic and pharmacodynamic profiles, hence altering their anticoagulant activity and increasing the risk of bleeding. In this regard, although direct oral anticoagulants are convenient for the outpatient management of COVID-19 patients, caution is recommended, given their interaction with other drugs used to treat COVID-19 [93,94].

The use of heparins as anticoagulants is also indicated when taking into account the additional mechanisms of their action. In particular, heparin exhibits anti-inflammatory activity by inhibiting the recruitment of neutrophils into tissues, binding and neutralizing inflammatory cytokines and acute phase proteins, and potentially having a protective effect on the endothelium [95-98]. It also has been hypothesized that heparin may interfere with the interaction between the virus and the host cell via a nonspecific ion bond, and thus may contribute to reducing the frequency of infected cells in COVID-19 [96]. A number of studies have reported that the use of heparins in critically ill COVID-19 patients contributed to a decrease in the production of elevated cytokines (IL- 6 and TNF- $\alpha$ ) [99]. Additionally, heparin protects the endothelium [100]. There are also data that heparin interacts with spike proteins of several viruses, including the SARS-CoV-2 spike protein receptor-binding domain, suggesting that it may be able to modulate protein's interactions with the endothelium [101]. Due to these characteristics, LMWH remains as the best choice of anticoagulant for hospitalized patients with severe COVID-19.

However, despite evidence that heparin in prophylactic doses is effective in reducing mortality in severe COVID-19 patients, a number of studies have reported a high incidence of venous and even arterial thromboembolic complications (deep vein thrombosis, pulmonary embolism or in situ thrombosis in the pulmonary arteries, and arterial thrombosis), despite thromboprophylaxis, which raises the issue of increasing anticoagulant doses. Prospective studies are currently in progress to try to answer this question $[5,102,103]$.

White et al. [104] also reported heparin resistance in COVID-19. According to the authors, out of 14 patients with COVID-19 associated coagulopathy and with a high risk of thrombosis, who were treated with LMWH or UFH, resistance to UFH was documented in $8 / 10(80 \%)$ patients, and suboptimal peak anti-Xa following therapeutic LMWH in $5 / 5(100 \%)$ patients.

There is also the problem of anticoagulants' optimal dose strategy. For example, a reduction in mortality in hospitalized patients with COVID-19 is shown when using a therapeutic, but not a preventive, dose of anticoagulants [12,13,105].

Taking into account the high frequency of thromboembolic complications, the International Society on Thrombosis and Haemostasis' guidelines continue to recommend thromboprophylaxis for all hospitalized patients, and in most patients with COVID-19, thromboprophylaxis should be continued after hospital discharge [9].

The Expert Group of American Society of Hematology recommended the use of prophylactic-intensity anticoagulation compared to moderate-intensity or therapeuticintensity anticoagulants for critical COVID-19-related patients or acute COVID-19 patients who do not have a confirmed VTE [106]. Taking into consideration their activation and their role in the clot formations, platelets are a potential target for the prevention of complications in SARS-CoV-2 infection [78,107-109]. The most commonly used antiplatelet agents are aspirin, clopidogrel, lopinavir/ritonavir, vorapaxar, and dipyridamole [109-112]. Among the antiplatelet agents, aspirin and clopidogrel are associated with decreased risk of ARDS, as well as decreased mortality among critically ill COVID-19 patients [111,112].

Vorapaxar and dipyridamole are considered promising antiplatelet agents for the treatment of COVID-19. Vorapaxar exhibits its antiplatelet activity through the antagonism of protease-activated receptor 1 (PAR-1), which plays an important role in thrombininduced platelet aggregation, and is associated with blood clotting and inflammation [113].

For example, Liu et al. [110] used dipyridamole with a positive clinical effect. However, these authors note that there are a number of questions regarding the use of antiplatelet drugs in COVID-19 treatment, and therefore additional clinical trials are needed [110]. 
The data presented above indicate that anticoagulant and antithrombotic therapy play a key role in the treatment of hemostasis disorders in COVID-19, but there are still a number of unresolved issues regarding the use of these drugs. Thus, the optimal effective anticoagulant and antithrombotic agents, as well as their doses, remain uncertain.

A separate problem is the interaction of antithrombotic and anticoagulant drugs with specific drugs in COVID-19 treatments, since not all drugs are compatible. An individual approach to the patient is recommended, aimed at the optimal risk/benefit ratio of various antithrombotic strategies, taking into account the underlying hypercoagulable state.

Therefore, the treatment of patients and prevention of thrombosis in COVID-19 requires solving issues related to the need to find new effective anticoagulants, as well as their optimal dosage. In this regard, the search for new effective anticoagulants remains relevant. In this aspect, the sulfated PSs of seaweed are of interest.

Diagnostic criteria for assessing hemostasis are the following coagulation-based laboratory parameters: both basic tests, including PT with international normalized ratio (INR), APTT, TT, fibrinogen level, platelet count, and extended parameters-AT III and D-dimer level. So, the COVID-19-associated coagulopathy (CAC) markers are prolongation of APTT and PT, hypofibrinogenemia or hyperfibrinogenemia, thrombocytopenia, a decrease or increase in AT III level, progressive decrease in the fibrinogen level, and an increase in the concentration of D-dimer. An increase in the D-dimer level correlates with higher mortality, and rapidly increasing hypofibrinogenemia foreshadows the development of DIC $[3,72,114,115]$. In general, such parameters as D-dimer, PT, platelet count, and fibrinogen are important predictors of critical conditions, and are of particular prognostic significance in patients with COVID-19.

As follows from our review, the major therapeutic role of seaweed sulfated PSs, as well as heparin, is in the inhibition of clot formation. Due to anticoagulant, antithrombotic, and fibrinolytic activities, it is possible to use PSs both for the purposes of thrombosis prevention and for thrombolysis. The mechanisms of anticoagulant and antithrombotic activity of seaweed sulfated PSs include the impact on both the factors of the extrinsic and intrinsic coagulation pathways, and the final stage of coagulation-the conversion of fibrinogen to fibrin under the thrombin influence. Anticoagulant activity of PS can be associated with plasma AT III, and antithrombotic activity-with an increase in the level of t-PA and competitive binding to the t-PA-PAI-1 complex. In this regard, seaweed sulfated PSs can contribute to normalization of the coagulation-based laboratory parameters (APTT, PT, AT III, D-dimer, and fibrinogen level); i.e., correction of hemostasis disorders in COVID19 patients.

The use of seaweed sulfated PSs, as well as heparin drugs, for the prevention and treatment of thrombosis is promising both at the stage of hospitalization of patients, and after discharge from the hospital. PSs can also be recommended for use in the outpatient setting for a long time.

In addition to being strong anticoagulants, antithrombotics, and fibrinolytics, PSs are also able to exhibit other effects that are useful in the treatment of viral infections, accounting for known data on their antiviral activity [116-119], anti-inflammatory activity, and ability to reduce the proinflammatory cytokine production and other beneficial effects $[17,56,120-124]$. Such a wide range of biological activity is due to the chemical nature of PSs. As is known, seaweed sulfated PSs, as well as heparins, are mimetics of glycosaminoglycans (GAGs). In mammalians, GAGs in the composition of proteoglycans are constituents of connective tissue. The polyanionic nature and the ability to interact with proteins with different affinities are properties of GAGs that determine their biological function and their role as a potential agents in various applications. So, GAGs such as heparin or seaweed sulfated polysaccharides are capable of interacting with factors of the coagulation cascade during clotting-inhibition processes [125]. GAGs also are exploited by numerous microorganisms for cellular attachment, adhesion, and invasion and evasion of the host's immune system. As for SARS-CoV and other coronaviruses, they can bind to 
host cells by clinging through their GAG [125]. In this regard, numerous works are devoted to the anticoronavirus ability of PSs [126-128].

\section{Conclusions}

Seaweed sulfated polysaccharides (PS) possess anticoagulant, antithrombotic, and fibrinolytic properties. These activities depends on the structural features (content and position of sulfate groups on the main chain of the PSs, molecular weight, monosaccharide composition and type of glycosidic bonds, the degree of PS chain branching, etc.). Sulfated PSs act on the hemostasis system both directly and indirectly and affect the factors of the extrinsic and intrinsic coagulation pathways, as well as the final stage of coagulation or the conversion of fibrinogen to fibrin under the thrombin influence. Anticoagulant activity of PS can be associated with plasma AT III, and antithrombotic activity-with an increase in the level of t-PA and competitive binding to the t-PA-PAI-1 complex.

The combination of the anticoagulant, antithrombotic, and fibrinolytic properties allows us to consider seaweed sulfated PSs as alternative sources of new anticoagulant and antithrombotic compounds. In this regard, and along with the low toxicity and relative low cost of their production, sulfated PSs are promising for clinical use and represent an alternative to heparin. The wide therapeutic potential of seaweed sulfated PSs, including anticoagulant, thrombolytic, and fibrinolytic activities, opens up new possibilities for their study in experimental and clinical trials. These natural compounds can be important complementary drugs in the fight against coronaviruses due to their natural origin, safety, and low cost compared to synthetic drugs. However, further investigations are needed regarding the use of seaweed PSs as potential anticoagulants, thrombolytics, and fibrinolytics aimed to correct hemostasis disorders in COVID-19 patients.

Author Contributions: Concept, methodology, writing, approval of the final review, T.A.K.; idea and writing plan, approval of the final version, collection and analysis of literature, preparation of the draft manuscript, B.G.A.; collection of material, verification and proofreading of technical details and terms, I.D.M.; proofreading the article, T.S.Z.; editing and validation of the article, N.N.B.; analysis and interpretation of data, L.N.F.; methodology, conceptualization, validation, S.P.K.; methodology, conceptualization, validation, M.Y.S. All authors have read and agreed to the published version of the manuscript.

Funding: This work was supported by the RFBR grant 20-04-60212, "Integrated ecological and virological monitoring of coronaviruses in the ecosystems of the Far East".

Institutional Review Board Statement: Not applicable.

Informed Consent Statement: Not applicable.

Conflicts of Interest: The authors declare no conflict of interest.

\section{References}

1. Belen-Apak, F.B.; Sarialioğlu, F. Pulmonary intravascular coagulation in COVID-19: Possible pathogenesis and recommendations on anticoagulant/thrombolytic therapy. J. Thromb. Thrombolysis 2020, 50, 278-280. [CrossRef]

2. Iba, T.; Levy, J.H.; Levi, M.; Connors, J.M.; Thachil, J. Coagulopathy of coronavirus disease. Crit. Care Med. 2020, 48, 1358-1364. [CrossRef]

3. Tang, N.; Li, D.; Wang, X.; Sun, Z. Abnormal coagulation parameters are associated with poor prognosis in patients with novel coronavirus pneumonia. J. Thromb. Haemost. 2020, 18, 844-847. [CrossRef] [PubMed]

4. Berkman, S.A.; Tapson, V.F. COVID-19 and Its Implications for Thrombosis and Anticoagulation. Semin Respir Crit. Care Med. 2021, 42, 316-326. [CrossRef]

5. Klok, F.A.; Kruip, M.; van der Meer, N.J.M.; Arbous, M.S.; Gommers, D.; Kant, K.M.; Kaptein, H.J.; van Paassen, J.; Stals, M.A.M.; Huisman, M.V.; et al. Incidence of thrombotic complications in critically ill ICU patients with COVID-19. Thromb. Res. 2020, 191, 145-147. [CrossRef] [PubMed]

6. Tan, B.K.; Mainbourg, S.; Friggeri, A.; Bertoletti, L.; Douplat, M.; Dargaud, Y.; Grange, C.; Lobbes, H.; Provencher, S.; Lega, J.C. Arterial and venous thromboembolism in COVID-19: A study-level meta-analysis. Thorax 2021, 23. [CrossRef]

7. Tang, N.; Bai, H.; Chen, X.; Gong, J.; Li, D.; Sun, Z. Anticoagulant treatment is associated with decreased mortality in severe coronavirus disease 2019 patients with coagulopathy. J. Thromb. Haemost. 2020, 18, 1094-1099. [CrossRef] [PubMed] 
8. Thachil, J.; Tang, N.; Gando, S.; Falanga, A.; Cattaneo, M.; Levi, M.; Clark, C.; Iba, T. ISTH interim guidance on recognition and management of coagulopathy in COVID-19. J. Thromb. Haemost. 2020, 18, 1023-1026. [CrossRef]

9. Kollias, A.; Kyriakoulis, K.G.; Dimakakos, E.; Poulakou, G.; Stergiou, G.S.; Syrigos, K. Thromboembolic risk and anticoagulant therapy in COVID-19 patients: Emerging evidence and call for action. Br. J. Haematol. 2020, 189, 846-847. [CrossRef] [PubMed]

10. Jonmarker, S.; Hollenberg, J.; Dahlberg, M.; Stackelberg, O.; Litorell, J.; Everhov, Å.H.; Järnbert-Pettersson, H.; Söderberg, M.; Grip, J.; Schandl, A.; et al. Dosing of thromboprophylaxis and mortality in critically ill COVID-19 patients. Crit. Care 2020, $24,653$. [CrossRef] [PubMed]

11. Kharma, N.; Roehrig, S.; Shible, A.A.; Elshafei, M.S.; Osman, D.; Elsaid, I.M.; Mustafa, S.F.; Aldabi, A.; Smain, O.A.M.; Lance, M.D. Anticoagulation in critically ill patients on mechanical ventilation suffering from COVID-19 disease, The ANTI-CO trial: A structured summary of a study protocol for a randomized controlled trial. Trials 2020, 21, 769. [CrossRef] [PubMed]

12. Lemos, A.C.B.; do Espírito Santo, D.A.; Salvetti, M.C.; Gilio, R.N.; Agra, L.B.; Pazin-Filho, A.; Miranda, C.H. Therapeutic versus prophylactic anticoagulation for severe COVID-19: A randomized phase II clinical trial (HESACOVID). Thromb. Res. 2020, 196, 359-366. [CrossRef]

13. Paranjpe, I.; Fuster, V.; Lala, A.; Russak, A.J.; Glicksberg, B.S.; Levin, M.A.; Charney, A.W.; Narula, J.; Fayad, Z.A.; Bagiella, E.; et al. Association of treatment dose anticoagulation within-hospital survival among hospitalized patients with COVID-19. J. Am. Coll. Cardiol. 2020, 76, 122-124. [CrossRef] [PubMed]

14. Wells, M.L.; Potin, P.; Craigie, J.S.; Raven, J.A.; Merchant, S.S.; Helliwell, K.E.; Smith, A.G.; Camire, M.E.; Brawley, S.H. Algae as nutritional and functional food sources: Revisiting our understanding. J. Appl. Phycol. 2017, 29, 949-982. [CrossRef]

15. Springer, G.F.; Wurzel, H.A.; McNeal, G.M.J.; Doughty, M.F. Isolation of anticoagulant fractions from crude fucoidan. Proc. Soc. Exp. Biol. Med. 1957, 94, 404-409. [CrossRef] [PubMed]

16. Hahn, T.; Lang, S.; Ulber, R.; Muffler, K. Novel procedures for the extraction of fucoidan from brown algae. Process Biochem. 2012, 47, 1691-1698. [CrossRef]

17. Menshova, R.V.; Shevchenko, N.M.; Imbs, T.I.; Zvyagintseva, T.N.; Maluarenko, O.S.; Zaporoshets, T.S.; Besednova, N.N.; Ermakova, S.P. Fucoidans from brown alga Fucus evanescens: Structure and biological activity. Front. Mar. Sci. 2016, 3. [CrossRef]

18. Ngo, D.H.; Kim, S.K. Sulfated polysaccharides as bioactive agents from marine algae. Int. J. Boil. Macromol. 2013, 62, 70-75. [CrossRef]

19. Chi, Y.; Li, H.; Wang, P.; Du, C.; Ye, H.; Zuo, S.; Guan, H.; Wang, P. Structural characterization of ulvan extracted from Ulva clathRata assisted by an ulvan lyase. Carbohydr. Polym. 2020, 229, 115497. [CrossRef] [PubMed]

20. Tran, T.T.V.; Truong, H.B.; Tran, N.H.V.; Quach, T.M.T.; Nguyen, T.N.; Bui, M.L.; Yuguchi, Y.; Thanh, T.T.T. Structure, conformation in aqueous solution and antimicrobial activity of ulvan extracted from green seaweed Ulva reticulate. Nat. Prod. Res. 2018, 32, 2291-2296. [CrossRef]

21. Tziveleka, L.A.; Ioannou, E.; Roussis, V. Ulvan, a bioactive marine sulphated polysaccharide as a key constituent of hybrid biomaterials: A review. Carbohydr. Polym. 2019, 218, 355-370. [CrossRef]

22. Wang, S.; Wang, W.; Hou, L.; Qin, L.; He, M.; Li, W.; Mao, W. A sulfated glucuronorhamnan from the green seaweed Monostroma nitidum: Characteristics of its structure and antiviral activity. Carbohydr. Polym. 2020, 227, 115280. [CrossRef]

23. Yu, Y.; Li, Y.; Du, C.; Mou, H.; Wang, P. Compositional and structural characteristics of sulfated polysaccharide from Enteromorpha prolifera. Carbohydr. Polym. 2017, 165, 221-228. [CrossRef]

24. Shen, Y.R.; Kuo, M.I. Effects of different carrageenan types on the rheological and water-holding properties of tofu. LWT 2017, 78, 122-128. [CrossRef]

25. Torres, M.; Flórez-Fernández, N.; Domínguez, H. Integral Utilization of Red Seaweed for Bioactive Production. Mar. Drugs 2019, 17, 314. [CrossRef] [PubMed]

26. Yegappan, R.; Selvaprithiviraj, V.; Amirthalingam, S.; Jayakumar, R. Carrageenan based hydrogels for drug delivery, tissue engineering and wound healing. Carbohydr. Polym. 2018, 198, 385-400. [CrossRef]

27. Athukorala, Y.; Jung, W.K.; Vasanthan, T.; Jeon, Y.J. An anticoagulative polysaccharide from an enzymatic hydrolysate of Ecklonia cava. Carbohydr. Polym. 2006, 66, 184-191. [CrossRef]

28. Mestechkina, N.M.; Shcherbukhin, V.D. Sulfated polysaccharides and their anticoagulant activity: A review. Prikl. Biokhim. Mikrobiol. 2010, 46, 291-298. (In Russian) [CrossRef] [PubMed]

29. Silva, T.M.A.; Alves, L.G.; Queiroz, K.C.S.; Santos, M.G.L.; Marques, C.T.; Chavante, S.F.; Rocha, H.A.O.; Leite, E.L. Partial characterization and anticoagulant activity of a heterofucan from the brown seaweed Padina gymnospora. Braz. J. Med. Biol. Res. 2005, 38, 523-533. [CrossRef]

30. Wang, J.; Zhang, Q.B.; Zhang, Z.S.; Song, H.; Li, P. Potential antioxidant and anticoagulant capacity of low molecular weight fucoidan fractions extracted from Laminaria japonica. Int. J. Biol. Macromol. 2010, 46, 6-12. [CrossRef]

31. Minh Thu, Q.T.; Luong, D.V.; Nu, N.T.; Thanh Van, T.T.; Ly, B.M.; Thu Thuy, T.T. Effect of sulfation on the structure and anticoagulant activity of ulvan extracted from green seaweed Ulva reticulata. Vietnam J. Sci. Technol. 2016, 54, 373-379. [CrossRef]

32. Liu, X.; Du, P.; Liu, X.; Cao, S.; Qin, L.; He, M.; He, X.; Mao, W. Anticoagulant properties of a green algal rhamnan-type sulfated polysaccharide and its low-molecular-weight fragments prepared by mild acid degradation. Mar. Drugs 2018, 16, 445. [CrossRef] [PubMed]

33. Adrien, A.; Bonnet, A.; Dufour, D.; Baudouin, S.; Maugard, T.; Bridiau, N. Anticoagulant activity of sulfated ulvan isolated from the green macroalga Ulva rigida. Mar. Drugs 2019, 17, 291. [CrossRef] [PubMed] 
34. Li, H.; Mao, W.; Zhang, X.; Qi, X.; Chen, Y.; Chen, Y.; Xu, J.; Zhao, C.; Hou, Y.; Yang, Y.; et al. Structural characterization of an anticoagulant-active sulfated polysaccharide isolated from green alga Monostroma latissimum. Carbohydr. Polym. 2011, 85, 394-400. [CrossRef]

35. Synytsya, A.; Choi, D.J.; Pohl, R.; Na, Y.S.; Capek, P.; Lattová, E.; Taubner, T.; Choi, J.W.; Lee, C.W.; Park, J.K.; et al. Structural features and anti-coagulant activity of the sulphated polysaccharide SPS-CF from a green alga Capsosiphon fulvescens. Mar. Biotechnol. 2015, 17, 718-735. [CrossRef] [PubMed]

36. Yoon, S.J.; Pyun, Y.R.; Hwang, J.K.; Mourão, P.A.S. A sulfated fucan from the brown alga Laminaria cichorioides has mainly heparin cofactor II-dependent anticoagulant activity. Carbohyd. Res. 2007, 342, 2326-2330. [CrossRef]

37. Yang, C.; Chung, D.; Shin, I.S.; Lee, H.; Kim, J.; Lee, Y.; You, S. Effects of molecular weight and hydrolysis conditions on anticancer activity of fucoidans from sporophyll of Undaria pinnatifida. Int. J. Biol. Macromol. 2008, 43, 433-437. [CrossRef] [PubMed]

38. Pomin, V.H.; Pereira, M.S.; Valente, A.P.; Tollefsen, D.M.; Pavão, M.S.; Mourão, P.A. Selective cleavage and anticoagulant activity of a sulfated fucan: Stereospecific removal of a 2-sulfate ester from the polysaccharide by mild acid hydrolysis, preparation of oligosaccharides, and heparin cofactor II-dependent anticoagulant activity. Glycobiology 2005, 15, 369-381. [CrossRef] [PubMed]

39. Boisson-Vidal, C.; Chaubet, F.; Chevolot, L.; Sinquin, C.; Theveniaux, J.; Millet, J.; Sternberg, C.; Mulloy, B.; Fischer, A.M. Relationship between antithrombotic activities of fucans and their structure. Drug. Dev. Res. 2000, 51, 216-224. [CrossRef]

40. Lahrsen, E.; Schoenfeld, A.K.; Alban, S. Size-dependent pharmacological activities of differently degraded fucoidan fractions from Fucus vesiculosus. Carbohyd. Polym. 2018, 189, 162-168. [CrossRef]

41. Choi, Y.; Min, S.K.; Usoltseva, R.; Silchenko, A.; Zvyagintseva, T.; Ermakova, S.; Kim, J.K. Thrombolytic fucoidans inhibit the tPA-PAI1 complex, indicating activation of plasma tissue-type plasminogen activator is a mechanism of fucoidan-mediated thrombolysis in a mouse thrombosis model. Thromb. Res. 2018, 161, 22-25. [CrossRef] [PubMed]

42. Min, S.K.; Han, S.M.; Jang, J.S.; Kim, J.K. Stimulatory effect of an algal fucoidan on the release of vascular endothelial tissue-type plasminogen activator as a mechanism of fucoidan-mediated thrombolysis. Blood Coagul. Fibrinolysis 2016, 27, 594-596. [CrossRef] [PubMed]

43. Cao, S.; He, X.; Qin, L.; He, M.; Yang, Y.; Liu, Z.; Mao, W. Anticoagulant and antithrombotic properties in vitro and in vivo of a novel sulfated polysaccharide from marine green alga Monostroma nitidum. Mar. Drugs 2019, 17, 247. [CrossRef] [PubMed]

44. Juenet, M.; Aid-Launais, R.; Li, B.; Berger, A.; Aerts, J.; Ollivier, V.; Nicoletti, A.; Letourneur, D.; Chauvierre, C. Thrombolytic therapy based on fucoidan-functionalized polymer nanoparticles targeting P-selectin. Biomaterials 2018, 156, 204-216. [CrossRef] [PubMed]

45. Hall, G.; Lang, D.; Qiu, X.; Doctor, V. Effect of native fucoidan, sulfated fucoidan, heparin and 6-aminohexanoic acid on the activation of glutamic-plasminogen by urokinase: Role of NaCl. Blood Coagul. Fibrinolysis 2006, 17, 277-281. [CrossRef] [PubMed]

46. Qiu, X.; Amarasekara, A.S.; Doctor, V.M. Effect of oversulfation on the chemical and biological properties of fucoidan. Carbohydr. Polym. 2006, 63, 224-228. [CrossRef]

47. Alvarez, G.F.; Bihari, D.; Collins, D. Heparin-induced thrombosis with a normal platelet count. Crit. Care Resusc. 2007, 9, 51-53. Available online: https:/ / pubmed.ncbi.nlm.nih.gov/17352667 (accessed on 23 April 2020). [PubMed]

48. Castelli, R.; Cassinerio, E.; Cappellini, M.D.; Porro, F.; Graziadei, G.; Fabris, F. Heparin induced thrombocytopenia: Pathogenetic, clinical, diagnostic and therapeutic aspects. Cardiovasc. Hematol. Disord. Drug Targets 2007, 7, 153-162. [CrossRef] [PubMed]

49. Suleria, H.A.R.; Masci, P.P.; Zhao, K.N.; Addepalli, R.; Chen, W.; Osborne, S.A.; Gobe, G.C. Anti-coagulant and anti-thrombotic properties of blacklip abalone (Haliotis rubra): In Vitro and animal studies. Mar. Drugs 2017, 15, 240. [CrossRef]

50. Ludwig, R.J. Therapeutic use of heparin beyond anticoagulation. Curr. Drug Discov. Technol. 2009, 6, 281-289. [CrossRef]

51. Melo, F.R.; Pereira, M.S.; Foguel, D.; Mourão, P.A.S. Antithrombin-mediated anticoagulant activity of sulfated polysaccharides: Different mechanisms for heparin and sulfated galactans. J. Biol. Chem. 2004, 279, 20824-20835. [CrossRef] [PubMed]

52. Kuznetsova, T.A.; Besednova, N.N.; Mamaev, A.N.; Momot, A.P.; Shevchenko, N.M.; Zvyagintseva, T.N. Anticoagulant activity of fucoidan from brown algae Fucus evanescens of the Okhotsk Sea. Bull. Exp. Biol. Med. 2003, 136, 471-473. [CrossRef]

53. Lapikova, E.S.; Drozd, N.N.; Tolstenkov, A.S.; Makarov, V.A.; Zvyagintseva, T.N.; Shevchenko, N.M.; Bakunina, I.U.; Besednova, N.N.; Kuznetsova, T.A. Inhibition of thrombin and factor Xa by Fucus evanescens fucoidan and its modified analogs. Bull. Exp. Biol. Med. 2008, 146, 328-333. [CrossRef]

54. Jung, W.K.; Athukorala, Y.; Lee, Y.J.; Cha, S.H.; Lee, C.H.; Vasanthan, T.; Choi, K.S.; Yoo, S.H.; Kim, S.K.; Jeon, Y.J. Sulfated polysaccharide purified from Ecklonia cava accelerates antithrombin III-mediated plasma proteinase inhibition. J. Appl. Phycol. 2007, 19, 425-430. [CrossRef]

55. Becker, C.F.; Guimarães, J.A.; Mourão, P.A.S.; Verli, H. Conformation of sulfated galactan and sulfated fucan in aqueous solutions: Implications to their anticoagulant activities. J. Mol. Graph. Model. 2007, 26, 391-399. [CrossRef] [PubMed]

56. Wang, Y.; Xing, M.; Cao, Q.; Ji, A.; Liang, H.; Song, S. Biological Activities of Fucoidan and the Factors Mediating Its Therapeutic Effects: A Review of Recent Studies. Mar. Drugs 2019, 17, 183. [CrossRef]

57. Li, N.; Zhang, Q.; Song, J. Toxicological evaluation of fucoidan extracted from Laminaria japonica in Wistar rats. Food Chem. Toxicol. 2005, 43, 421-426. [CrossRef] [PubMed]

58. Prasad, S.; Lillicrap, D.; Labelle, A.; Knappe, S.; Keller, T.; Burnett, E.; Powell, S.; Johnsjn, K.W. Efficacy and safety of a new-class hemostatic drug candidate, AV513, in dogs with hemophilia A. Blood 2008, 111, 672-679. [CrossRef] [PubMed]

59. Gideon, T.P.; Rengasamy, R. Toxicological evaluation of fucoidan from Cladosiphon okamuranus. J. Med. Food. 2008, 11, 638-642. [CrossRef] [PubMed] 
60. Zhao, X.; Guo, F.; Hu, J.; Zhang, L.; Xue, C.; Zhang, Z.; Li, B. Antithrombotic activity of oral administered low molecular weight fucoidan from Laminaria japonica. Thromb. Res. 2016, 144, 46-52. [CrossRef] [PubMed]

61. Varga, Z.; Flammer, A.J.; Steiger, P.; Haberecker, M.; Andermatt, R.; Zinkernagel, A.S.; Mehra, M.R.; Schuepbach, R.A.; Ruschitzka, F.; Moch, H. Endothelial cell infection and endotheliitis in COVID-19. Lancet 2020, 395, 1417-1418. [CrossRef]

62. Bavishi, C.; Maddox, T.M.; Messerli, F.H. Coronavirus Disease 2019 (COVID-19) infection and renin angiotensin system blockers. JAMA Cardiol. 2020, 5, 745-747. [CrossRef] [PubMed]

63. Connors, J.M.; Levy, J.H. COVID-19 and its implications for thrombosis and anticoagulation. Blood 2020, 135, 2033-2040. [CrossRef]

64. Levi, M.; Thachil, J.; Iba, T.; Levy, J.H. Coagulation abnormalities and thrombosis in patients with COVID-19. Lancet Haematol. 2020, 7, E438-E440. [CrossRef]

65. Marongiu, F.; Grandone, E.; Barcellona, D. Pulmonary thrombosis in 2019-nCoV pneumonia? J. Tromb. Haemost. 2020, 18, 1511-1513. [CrossRef]

66. Dhont, S.; Derom, E.; van Braeckel, E.; Depuydt, P.; Lambrecht, B.N. The pathophysiology of 'happy' hypoxemia in COVID-19. Respir. Res. 2020, 21, 198. [CrossRef]

67. Serebrovska, Z.O.; Chong, E.Y.; Serebrovska, T.V.; Tumanovska, L.V.; Xi, L. Hypoxia, HIF-1 $\alpha$, and COVID-19: From pathogenic factors to potential therapeutic targets. Acta Pharmacol. Sin. 2020, 41, 1539-1546. [CrossRef] [PubMed]

68. Zubieta-Calleja, G.; Zubieta-DeUrioste, N. Pneumolysis and «Silent Hypoxemia» in COVID-19. Indian J. Clin. Biochem. 2021, 36, 112-116. [CrossRef]

69. Qin, C.; Zhou, L.; Hu, Z.; Zhang, S.; Yang, S.; Tao, Y.; Xie, C.; Ma, K.; Shang, K.; Wang, W.; et al. Dysregulation of immune response in patients with COVID-19 in Wuhan, China. Clin. Infect. Dis. 2020, 71, 762-768. [CrossRef]

70. Vaninov, N. In the eye of the COVID-19 cytokine storm. Nat. Rev. Immunol. 2020, 20, 277. [CrossRef]

71. Liu, B.; Li, M.; Zhou, Z.; Guan, X.; Xiang, Y. Can we use interleukin-6 (IL-6) blockade for coronavirus disease 2019 (COVID-19)induced cytokine release syndrome (CRS)? J. Autoimmun. 2020, 111, 102452. [CrossRef] [PubMed]

72. Han, H.; Yang, L.; Liu, R.; Liu, F.; Wu, K.L.; Li, J.; Liu, X.H.; Zhu, C.L. Prominent changes in blood coagulation of patients with SARS-CoV-2 infection. Clin. Chem. Lab. Med. 2020, 58, 1116-1120. [CrossRef] [PubMed]

73. Li, Q.; Cao, Y.; Chen, L.; Wu, D.; Yu, J.; Wang, H.; He, W.; Chen, L.; Dong, F.; Chen, W.; et al. Hematological features of persons with COVID-19. Leukemia 2020, 34, 2163-2172. [CrossRef]

74. Yang, X.; Yang, Q.; Wang, Y.; Wu, Y.; Xu, J.; Yu, Y.; Shang, Y. Thrombocytopenia and its association with mortality in patients with COVID-19. J. Thromb. Haemost. 2020, 18. [CrossRef] [PubMed]

75. Liu, Y.; Sun, W.; Guo, Y.; Chen, L.; Zhang, L.; Zhao, S.; Long, D.; Yu, L. Association between platelet parameters and mortality in coronavirus disease 2019: Retrospective cohort study. Platelets 2020, 31, 490-496. [CrossRef] [PubMed]

76. Middeldorp, S.; Coppens, M.; van Haaps, T.F.; Foppen, M.; Vlaar, A.P.; Müller, M.C.; Bouman, C.C.; Beenen, L.F.; Kootte, R.S.; Heijmans, J.; et al. Incidence of venous thromboembolism in hospitalized patients with COVID-19. J. Thromb. Haemost. 2020, 18, 1995-2002. [CrossRef]

77. Joob, B.; Wiwanitkit, V. Hemorrhagic Problem Among the Patients With COVID-19: Clinical Summary of 41 Thai Infected Patients. Clin. Appl. Thromb. Hemost. 2020, 26, 1076029620918308. [CrossRef] [PubMed]

78. McFadyen, J.D.; Stevens, H.; Peter, K. The Emerging Threat of (Micro) Thrombosis in COVID-19 and Its Therapeutic Implications. Circ. Res. 2020, 127, 571-587. [CrossRef] [PubMed]

79. Xu, P.; Zhou, Q.; Xu, J. Mechanism of thrombocytopenia in COVID-19 patients. Ann. Hematol. 2020, 99, 1205-1208. [CrossRef]

80. Zhang, Y.; Zeng, X.; Jiao, Y.; Li, Z.; Liu, Q.; Ye, J.; Yang, M. Mechanisms involved in the development of thrombocytopenia in patients with COVID-19. Thromb. Res. 2020, 193, 110-115. [CrossRef]

81. Lippi, G.; Plebani, M.; Henry, B.M. Thrombocytopenia is associated with severe coronavirus disease 2019 (COVID-19) infections: A meta-analysis. Clin. Chim. Acta 2020, 506, 145-148. [CrossRef] [PubMed]

82. Amgalan, A.; Othman, M. Exploring possible mechanisms for COVID-19 induced thrombocytopenia: Unanswered Questions. J. Thromb. Haemost. 2020, 18, 1514-1516. [CrossRef]

83. Spadarella, G.; Di Minno, A.; Donati, M.B.; Mormile, M.; Ventre, I.; Di Minno, G. From unfractionated heparin to pentasaccharide: Paradigm of rigorous science growing in the understanding of the in vivo thrombin generation. Blood Rev. 2020, 39, 10061. [CrossRef]

84. Hirsh, J.; Raschke, R. Heparin and low-molecular-weight heparin: The Seventh ACCP Conference on Antithrombotic and Thrombolytic Therapy. Chest 2004, 126, 188S-203S. [CrossRef]

85. Rezaie, A.R. Prothrombin protects factor $\mathrm{Xa}$ in the prothrombinase complex from inhibition by the heparin-antithrombin complex. Blood 2001, 97, 2308-2313. [CrossRef] [PubMed]

86. Bianchini, P.; Liverani, L.; Spelta, F.; Mascellani, G.; Parma, B. Variability of Heparins and Heterogeneity of Low Molecular Weight Heparins. Semin Thromb Hemost. 2007, 33, 496-502. [CrossRef]

87. Navarese, E.P.; De Luca, G.; Castriota, F.; Kozinski, M.; Gurbel, P.A.; Gibson, C.M.; Andreotti, F.; Buffon, A.; Siller-Matula, J.M.; Sukiennik, A.; et al. Low-molecular-weight heparins vs. unfractionated heparin in the setting of percutaneous coronary intervention for ST-elevation myocardial infarction: A meta-analysis. J. Thromb. Haemost. 2011, 9, 1902-1915. [CrossRef] [PubMed]

88. Padilla, A.; Gray, E.; Pepper, D.S.; Barrowcliffe, T.W. Inhibition of thrombin generation by heparin and low molecular weight (LMW) heparins in the absence and presence of platelet factor 4 (PF4). Br. J. Haematol. 1992, 82, 406-413. [CrossRef] [PubMed] 
89. Qian, Y.; Xie, H.; Tian, R.; Yu, K.; Wang, R. Efficacy of low molecular weight heparin in patients with acute exacerbation of chronic obstructive pulmonary disease receiving ventilatory support. COPD 2014, 11, 171-176. [CrossRef]

90. Cohen, A.T.; Davidson, B.L.; Gallus, A.S.; Lassen, M.R.; Prins, M.H.; Tomkowski, W.; Turpie, A.G.; Egberts, J.F.; Lensing, A.W.; ARTEMIS Investigators. Efficacy and safety of fondaparinux for the prevention of venous thromboembolism in older acute medical patients: Randomised placebo controlled trial. BMJ 2006, 332, 325-329. [CrossRef] [PubMed]

91. Al-Ani, F.; Chehade, S.; Lazo-Langner, A. Thrombosis risk associated with COVID-19 infection. A scoping review. Thromb. Res. 2020, 192, 152-160. [CrossRef] [PubMed]

92. Testa, S.; Prandoni, P.; Paoletti, O.; Morandini, R.; Tala, M.; Dellanoce, C.; Giorgi-Pierfranceschi, M.; Betti, M.; Danz, G.B.; Pan, A.; et al. Direct oral anticoagulant plasma levels' striking increase in severe COVID-19 respiratory syndrome patients treated with antiviral agents: The Cremona experience. J. Thromb. Haemost. 2020, 18, 1320-1323. [CrossRef]

93. University of Liverpool. COVID-19 Drug Interactions. Available online: https://www.covid19-druginteractions.org/prescribingresources (accessed on 23 April 2020).

94. Marietta, M.; Ageno, W.; Artoni, A.; De Candia, E.; Gresele, P.; Marchetti, M.; Marcucci, R.; Tripodi, A. COVID-19 and haemostasis: A position paper from Italian society on thrombosis and haemostasis (SISET). Blood Transfus. 2020, 18, 167-169. [CrossRef] [PubMed]

95. Young, E. The anti-inflammatory effects of heparin and related compounds. Thromb. Res. 2008, 122, 743-752. [CrossRef]

96. Thachil, J. The versatile heparin in COVID-19. J. Thromb. Haemost. 2020, 18, 1020-1022. [CrossRef]

97. Tichelaar, Y.I.; Kluin-Nelemans, H.J.; Meijer, K. Infections and inflammatory diseases as risk factors for venous thrombosis. A systematic review. Thromb. Haemost. 2012, 107, 827-837. [CrossRef]

98. Poterucha, T.J.; Libby, P.; Goldhaber, S.Z. More than an anticoagulant: Do heparins have direct anti-inflammatory effects? Thromb. Haemost. 2017, 117, 437-444. [CrossRef] [PubMed]

99. Atallah, B.; Mallah, S.I.; AlMahmeed, W. Anticoagulation in COVID-19. Eur. Heart J. Cardiovasc. Pharmacother. 2020, 6, 260-261. [CrossRef] [PubMed]

100. Mitchell, W.B. Thromboinflammation in COVID-19 acute lung injury. Paediatr. Respir. Rev. 2020, 35, 20-24. [CrossRef]

101. Mycroft-West, C.; Su, D.; Elli, S.; Guimond, S.; Miller, G.; Turnbull, J.; Yates, E.; Guerrini, M.; Fernig, D.; Lima, M.; et al. The 2019 coronavirus (SARS-CoV-2) surface protein (Spike) S1 receptor binding domain undergoes conformational change upon heparin binding. BioRxiv 2020. [CrossRef]

102. Thomas, W.; Varley, J.; Johnston, A.; Symington, E.; Robinson, M.; Sheares, K.; Lavinio, A.; Besser, M. Thrombotic complications of patients admitted to intensive care with COVID-19 at a teaching hospital in the United Kingdom. Thromb. Res. 2020, 191, 76-77. [CrossRef] [PubMed]

103. Helms, J.; Tacquard, C.; Severac, F.; Leonard-Lorant, I.; Ohana, M.; Delabranche, X.; Merdji, H.; Clere-Jehl, R.; Schenck, M.; Fagot Gandet, F.; et al. High risk of thrombosis in patients with severe SARS-CoV-2 infection: A multicenter prospective cohort study. Intensive Care Med. 2020, 46, 1089-1098. [CrossRef] [PubMed]

104. White, D.; MacDonald, S.; Bull, T.; Hayman, M.; de Monteverde-Robb, R.; Sapsford, D.; Lavinio, A.; Varley, J.; Johnston, A.; Besser, M.; et al. Heparin resistance in COVID-19 patients in the intensive care unit. J. Thromb. Thrombolysis 2020, 50, $287-291$. [CrossRef] [PubMed]

105. Bulanov, A.Y.; Roitman, E.V. New coronavirus infection, hemostasis and heparin dosing problems: It is important to say now. Tromboz Gemostaz i Reologiya 2020, 2, 11-18. (In Russian) [CrossRef]

106. Cuker, A.; Tseng, E.K.; Nieuwlaat, R.; Angchaisuksiri, P.; Blair, C.; Dane, K.; Davila, J.; DeSancho, M.T.; Diuguid, D.; Griffin, D.O.; et al. American Society of Hematology 2021 guidelines on the use of anticoagulation for thromboprophylaxis in patients with COVID-19. Blood Adv. 2021, 5, 872-888. [CrossRef]

107. Fox, S.E.; Akmatbekov, A.; Harbert, J.L.; Li, G.; Quincy Brown, J.; Vander Heide, R.S. Pulmonary and cardiac pathology in Covid-19: The first autopsy series from New Orleans. Lancet Respir. Med. 2020, 8, 681-686. [CrossRef]

108. Kow, C.S.; Hasan, S.S. The use of antiplatelet agents for arterial thromboprophylaxis in COVID-19. Rev. Esp. Cardiol. 2021, 74, 114-115. [CrossRef]

109. Ranucci, M.; Ballotta, A.; Di Dedda, U.; Bayshnikova, E.; Dei Poli, M.; Resta, M.; Falco, M.; Albano, G.; Menicanti, L. The procoagulant pattern of patients with COVID-19 acute respiratory distress syndrome. J. Thromb. Haemost. 2020, 18, 1747-1751. [CrossRef]

110. Liu, X.; Li, Z.; Liu, S.; Sun, J.; Chen, Z.; Jiang, M.; Zhang, Q.; Wei, Y.; Wang, X.; Huang, Y.Y.; et al. Potential therapeutic effects of dipyridamole in the severely ill patients with COVID-19. Acta Pharm. Sin. B 2020, 10, 1205-1215. [CrossRef]

111. Panka, B.A.; de Grooth, H.J.; Spoelstra-de Man, A.M.; Looney, M.R.; Tuinman, P.R. Prevention or treatment of ARDS with aspirin: A review of preclinical models and meta-analysis of clinical studies. Shock 2017, 47, 13-21. [CrossRef] [PubMed]

112. Reilly, J.P.; Christie, J.D. Linking genetics to ARDS pathogenesis: The role of the platelet. Chest 2015, 147, 585-586. [CrossRef] [PubMed]

113. Bikdeli, B.; Madhavan, M.V.; Gupta, A.; Jimenez, D.; Burton, J.R.; Der Nigoghossian, C.; Chuich, T.; Nouri, S.N.; Dreyfus, I.; Driggin, E.; et al. Global COVID-19 Thrombosis Collaborative Group. Pharmacological Agents Targeting Thromboinflammation in COVID-19: Review and Implications for Future Research. Thromb. Haemost. 2020, 120, 1004-1024. [CrossRef] [PubMed]

114. Gao, Y.; Li, T.; Han, M.; Li, X.; Wu, D.; Xu, Y.; Zhu, Y.; Liu, Y.; Wang, X.; Wang, L. Diagnostic utility of clinical laboratory data determinations for patients with the severe COVID-19. J. Med. Virol. 2020, 92, 791-796. [CrossRef]

115. Wool, G.D.; Miller, J.L. Review Article. The Impact of COVID-19 Disease on platelets and coagulation. Pathobiology 2021, 88, 15-27. [CrossRef] 
116. Ahmadi, A.; Moghadamtousi, S.Z.; Abubakar, S.; Zandi, K. Antiviral Potential of Algae Polysaccharides Isolated from Marine Sources: A Review. BioMed. Res. Int. 2015, 10. [CrossRef]

117. Damonte, E.B.; Matulewicz, M.C.; Cerezo, A.S. Sulfated seaweed polysaccharides as antiviral agents. Curr. Med. Chem. 2004, 11, 2399-2419. [CrossRef]

118. Wang, W.; Wang, S.X.; Guan, H.S. The antiviral activities and mechanisms of marine polysaccharides: An overview. Mar. Drugs 2012, 10, 2795-2816. [CrossRef] [PubMed]

119. Zaporozhets, T.S.; Besednova, N.N. Biologically active compounds from marine organisms in the strategies for combating coronaviruses. Review. AIMS Microbiol. 2020, 6, 470-494. [CrossRef] [PubMed]

120. Apostolova, E.; Lukova, P.; Baldzhieva, A.; Katsarov, P.; Nikolova, M.; Iliev, I.; Peychev, L.; Trica, B.; Oancea, F.; Delattre, C.; et al. Immuno-modulatory and anti-inflammatory effects of fucoidan: A Review. Polymers 2020, 12, 2338. [CrossRef] [PubMed]

121. Cheung, R.C.F.; Ng, T.B.; Wong, J.H.; Chen, Y.; Chan, W.Y. Marine natural products with inflammatory activity. Appl. Microbiol. Biotechnol. 2016, 100, 1645-1666. [CrossRef]

122. Cui, M.; Wu, J.; Wang, S.; Shu, H.; Zhang, M.; Liu, K.; Liu, K. Characterization and anti-inflammatory effects of sulfated polysaccharide from the red seaweed Gelidium pacificum Okamura. Int. J. Biol. Macromol. 2019, 129, 377-385. [CrossRef]

123. Majee, S.B.; Avlani, D.; Biswas, G.R. Pharmacological, pharmaceutical, cosmetic and diagnostic applications of sulfated polysaccharides from marine algae and bacteria. Afr. J. Pharm. Pharmacol. 2017, 11, 68-77. [CrossRef]

124. Giriwono, P.E.; Iskandriati, D.; Tan, C.P.; Andarwulan, N. Sargassum seaweed as a source of anti-inflammatory substances and the potential insight of the tropical species: A review. Mar. Drugs 2019, 17, 590. [CrossRef]

125. Kim, S.Y.; Jin, W.; Sood, A.; Montgomery, D.W.; Grant, O.C.; Fuster, M.M.; Fu, L.; Dordick, J.S.; Woods, R.J.; Zhang, F.; et al. Characterization of heparin and severe acute respiratory syndrome-related coronavirus 2 (SARS-CoV-2) spike glycoprotein binding interactions. Antiviral Res. 2020, 181, 104873. [CrossRef]

126. Kwon, P.S.; Oh, H.; Kwon, S.J.; Jin, W.; Zhang, F.; Fraser, K.; Hong, J.J.; Linhardt, R.J.; Dordick, J.S. Sulfated polysaccharides effectively inhibit SARS-CoV-2 in vitro. Cell Discov. 2020, 6, 50. [CrossRef]

127. Hans, N.; Malik, A.; Naik, S. Antiviral activity of sulfated polysaccharides from marine algae and its application in combating COVID-19: Mini review. Biores. Technol. Rep. 2021, 13, 100623. [CrossRef]

128. Pagarete, A.; Ramos, A.S.; Puntervoll, P.; Allen, M.J.; Verdelho, V. Antiviral Potential of Algal Metabolites-A Comprehensive Review. Mar. Drugs 2021, 19, 94. [CrossRef] [PubMed] 